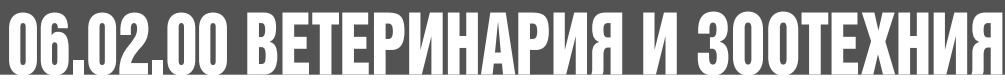

УДК 636.2

DOI 10.18286/1816-4501-2018-4-118-122

\section{ПОКАЗАТЕЛИ ТКАНЕВОГО МЕТАБОЛИЗМА ОРГАНИЗМА ЖИВОТНЫХ НА ФОНЕ ЦИТРАТЦЕОЛИТОВОЙ ДОБАВКИ}

\author{
Ахметова Венера Венератовна, кандидат биологических наук, \\ доцент кафедры «Морфология, физиология и патология животных» \\ Мухитов Асгат Завдетович, кандидат биологических наук, \\ доцент кафедры "Хирургия, акушерство, фармакология и терапия» \\ Пульчеровская Лидия Петровна, кандидат биологических наук, \\ дочент кафедры «Микробиология, вирусология, эпизоотология и ВСЭ» \\ ФГБОУ ВО УльяновскИй ГАУ \\ 432017, г. Ульяновск, бульвар Новый Венеи, 1; тел.: 8(8422)55-23-75; \\ e-mail: verenka1111@mail.ru
}

Ключевые слова: метаболизм, печень, мышца, животное, кормовая добавка, цеолит.

Целью данной работы стало изучение показателей тканевого метаболизма у молодняка свиней при использовании цеолита в комплексе с органическими кислотами. Эксперимент проведен в свиноводческом хозяйстве Ульяновской области Ульяновского района. Для опыта были выбраны аналоги по породе, живой массе, фризиологическому состоянию, возрасту и продуктивности молодняка свиней на доращивании до 210 дней. Схема скармливания добавок заключалась в том, что первая группа животных получала только основной хозяйственный рацион, эта группа являлась контролем. Второй группе поросят - опытной скармливали вместе с основным рационом природный цеолит месторождения Ульяновской области "Майнит» в дозе 2 \% от сухого вещества рациона. Третьей группе молодняка свиней добавляли раз в сутки к их основному рациону цитратцеолитовый комплекс, в состав которого входило 2 \% цеолита от сухого вещества рациона и 40 мг/кг лимонной кислоты. Доказано, что введение в рацион поросят цеолитовых добавок (отдельно и в комплексе с органическими кислотами) влияет на процессы метаболизма в тканях организма продуктивных животных. Под влиянием каталитических и ионообменных свойств добавок цеолита и цитратцеолитового комплекса происходит активизация фрерментных систем, синтеза тканевого белка в печени и мышечной ткани молодняка свиней, способствуя повышению энергии их роста. Установлено снижение детоксикационного напряжения печени свиней при скармливании цеолитовых добавок и комплекса на основе цеолита и органических кислот.

\section{Введение}

На фоне техногенного и антропогенного загрязнения окружающей среды актуальным становиться применения кормовых средств на основе природных цеолитов, способных выводить из организма животных и человека тяжелые металлы, токсины и радиоактивные вещества и получать экологически безопасную продукцию животноводства. Для Поволжского региона снижению экологического риска способствует использование в качестве кормовой подкормки естественных цеолитов, например «Майнита» (месторождения Ульяновской области) или «Воднита» (месторождения Самарской области) [1, 2, 3, 4, 5, 6].

Для коррекции нарушений метаболизма в организме животных эффективно использовать биологически активные комплексы. Научный поиск приводит учёных к разработке и применению в животноводстве комплексных добавок на основе природных цеолитов с включением биологически активных веществ, белковых компонентов, органических кислот и других веществ [7, 8, 9, 10, 
Целью данной работы стало изучение показателей тканевого метаболизма у молодняка свиней при использовании цеолита в комплексе с органическими кислотами.

Объекты и методы исследований

Эксперимент проведен в свиноводческом хозяйстве Ульяновской области Ульяновского района. Для опыта были выбраны аналоги по породе, живой массе, физиологическому состоянию, возрасту и продуктивности молодняк свиней на доращивании до 210 дней. Схема скармливания добавок заключалась в том, что первая группа животных получала только основной хозяйственный рацион, эта группа являлась контролем. Второй группе поросят - опытной скармливали вместе с основным рационом природный цеолит (Ц) месторождения Ульяновской области «Майнит» в дозе 2 \% от сухого вещества рациона. Третьей группе молодняка свиней на доращивании до 210 ней добавляли раз в сутки к их основному рациону цитратцеолитовый комплекс (ЦЦК), в состав которого входило 2 \% цеолита от сухого вещества рациона и 40 мг/кг лимонной кислоты. Убой животных проводили в конце опыта по 7 поросят из группы. Содержание белка, мочевины и ферментов в тканях определяли в гомогенатах на анализаторе «Stat Fax 1904 Plus». Bce данные обработаны на компьютере с использованием программы Statistika.

\section{Результаты исследований}

В ходе эксперимента полученные результаты позволили выявить некоторые закономерности влияния скармливания кормовых добавок

Биохимические показатели печени молодняка свиней 210 -дневного возраста при скармливании цЦК

\begin{tabular}{|c|c|c|c|}
\hline \multirow{2}{*}{ Показатель } & \multicolumn{3}{|c|}{ Группа } \\
\cline { 2 - 4 } & $\mathbf{1}$ & $\mathbf{2}$ & $\mathbf{3}$ \\
(контроль) & (ОР+Ц) & (ОР+ЦЦК) \\
\hline Белок, \% & $16,36 \pm 0,28$ & $17,45 \pm 0,35$ & $17,81 \pm 0,17$ \\
\hline$\%$ от контроля & 100,0 & 107,1 & 109,2 \\
\hline Мочевина, ммоль/л & $8,76 \pm 0,05$ & $7,79 \pm 0,09$ & $7,53 \pm 0,09$ \\
\hline \% от контроля & 100,0 & 89,2 & 86,4 \\
\hline $\begin{array}{c}\text { Аргиназа, мкмоль/ } \\
\text { (мин·мг) }\end{array}$ & $7,87 \pm 0,48$ & $7,17 \pm 0,33$ & $7,02 \pm 0,13$ \\
\hline \% от контроля & 100,0 & 91,0 & 89,0 \\
\hline
\end{tabular}

на основе цеолита и органических кислот на ряд показателей белкового обмена и функции печени молодняка свиней. Изучение содержания белка в печени поросят показало (табл. 1), что в опытных группах наблюдалась чёткая тенденция к увеличению на 7,1 и 9,2 \% соответственно по сравнению с контролем, где его уровень находился в пределах $16,36 \pm 0,28$ г/л. Установлено снижение концентрации мочевины на 10,8 и 13,6 \% во 2-й и 3-й группах.

Это указывает на усиление белкового метаболизма в организме поросят при использовании цеолитовых и цитратцеолитовых добавок и подтверждается динамикой активности аминотрансфераз (рис. 1). Нами отмечено, что активность основного фермента печени, характеризующего белковый обмен - аспартатаминотрансферазы (АСТ) у свиней опытных групп, где включали в ОР цеолит и цитратцеолитовый комплекс, отличалась от контроля тенденцией к снижению на 3,9 и 5,8\%.

В то же время изучение активности пече-

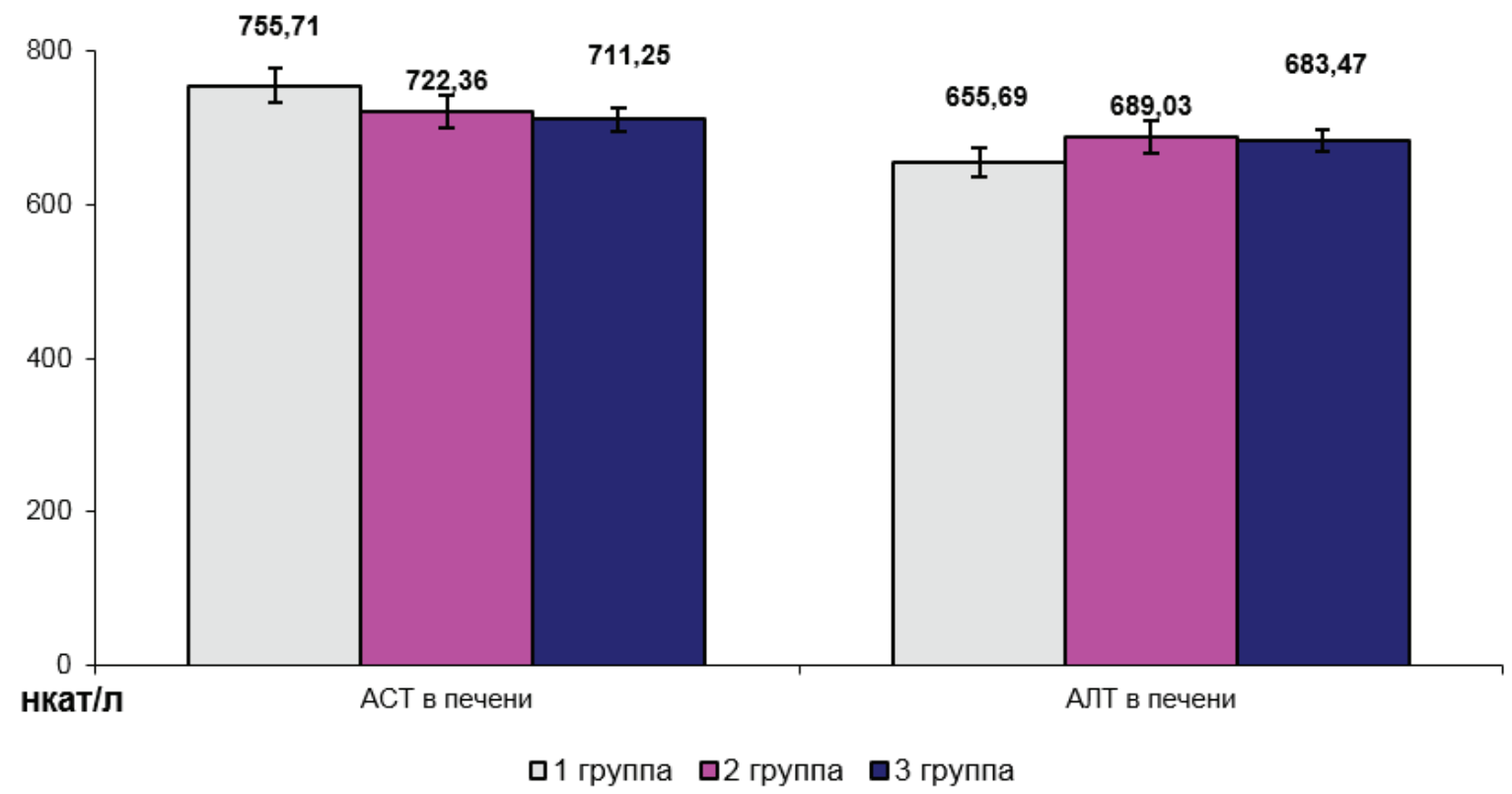

Рис. 1 - Активность аминотрансфераз в печени поросят 210 - дневного возраста при использовании цЦК 
Таблица 2

Биохимические показатели мышечной ткани молодняка свиней 210- дневного возраста при скармливании ЦЦК

\begin{tabular}{|c|c|c|c|}
\hline \multirow[b]{2}{*}{ Показатель } & \multicolumn{3}{|c|}{ Группа } \\
\hline & $\begin{array}{c}1 \\
\text { (контроль) }\end{array}$ & $\begin{array}{c}2 \\
\text { (OP+Ц) }\end{array}$ & $\begin{array}{c}3 \\
\text { (ОР+ЦЦК) }\end{array}$ \\
\hline Белок, \% & $17,45 \pm 0,03$ & $18,87 \pm 0,44$ & $18,93 \pm 0,85$ \\
\hline \% от контроля & 100,0 & 108,2 & 108,6 \\
\hline $\begin{array}{l}\text { Аргиназа, мкмоль/ } \\
\text { (мин·мг) }\end{array}$ & $3,97 \pm 0,53$ & $3,67 \pm 0,45$ & $3,23 \pm 0,87$ \\
\hline \% от контроля & 100,0 & 91,1 & 81,4 \\
\hline
\end{tabular}

ночного фермента аланинаминотрансферазы (АЛТ) выявило, напротив, слабую тенденцию к увеличению этого показателя как во 2-й, так и 3-й группе на 5,4 и 4,6 \% соответственно по сравнению с данными у аналогов в 1-й группе. В целом полученная динамика активности энзимов в печени свиней характеризует интенсификацию процессов переаминирования аминокислот в их организме под влиянием применяемых цеолитовых добавок.

В ходе опыта мы проводили изучение и мышечной ткани подопытных животных (табл. 2, рис. 2), которое выявило аналогичную закономерность к увеличению содержания тканевого белка в мышцах свиней на 8,2 и 8,6 \%, что свидетельствует также о повышении качества мяса

Определение активности аргиназы также свидетельствовало об уменьшении этого показателя и в мышечной ткани подопытных свиней соответственно на 8,9 и 8,6 \% по сравнению с контролем.
Активность аминотрансфераз в мышечной ткани животных опытных групп заметно возрастала по сравнению с контролем. Так, если в контроле активность АСТ составила 488,99 $\pm 15,78$ нкат/л, то в опытных группах она возросла на 5,1 и 7,3 \%. При этом активность АЛТ в мышечной ткани синей 1-й группы находилась в рамках 405,64 \pm 55,86 нкат/л, то во 2-й и 3-й группах увеличилась соответственно на 8,2 и 4,4 \% по сравнению с аналогами.

\section{Выводы}

1. Введение в сбалансированный по питательности рацион поросят на доращивании естественных цеолитовых добавок (отдельно и в комплексе с органическими кислотами) напрямую и косвенно влияет на процессы метаболизма в тканях организма продуктивных животных.

2. Под влиянием каталитических и ионообменных свойств добавок цеолита и цитратцеолитового комплекса происходит активизация ферментных систем, синтеза тканевого белка в печени и мышечной ткани молодняка свиней. Это, в свою очередь, окажет положительное влияние на рост и развитие поросят, повышая их интенсивность.

3. Снижение активности аргиназы в печени поросят опытных групп говорит об активизации процессов детоксикации аммония через уреазный цикл и подтверждается динамикой аминотрансфераз в печени. В целом это свидетельствует об уменьшении детоксикационного напряжения печени при скармливании цеолитовых добавок и комплексов на основе цеолита и органических кислот.

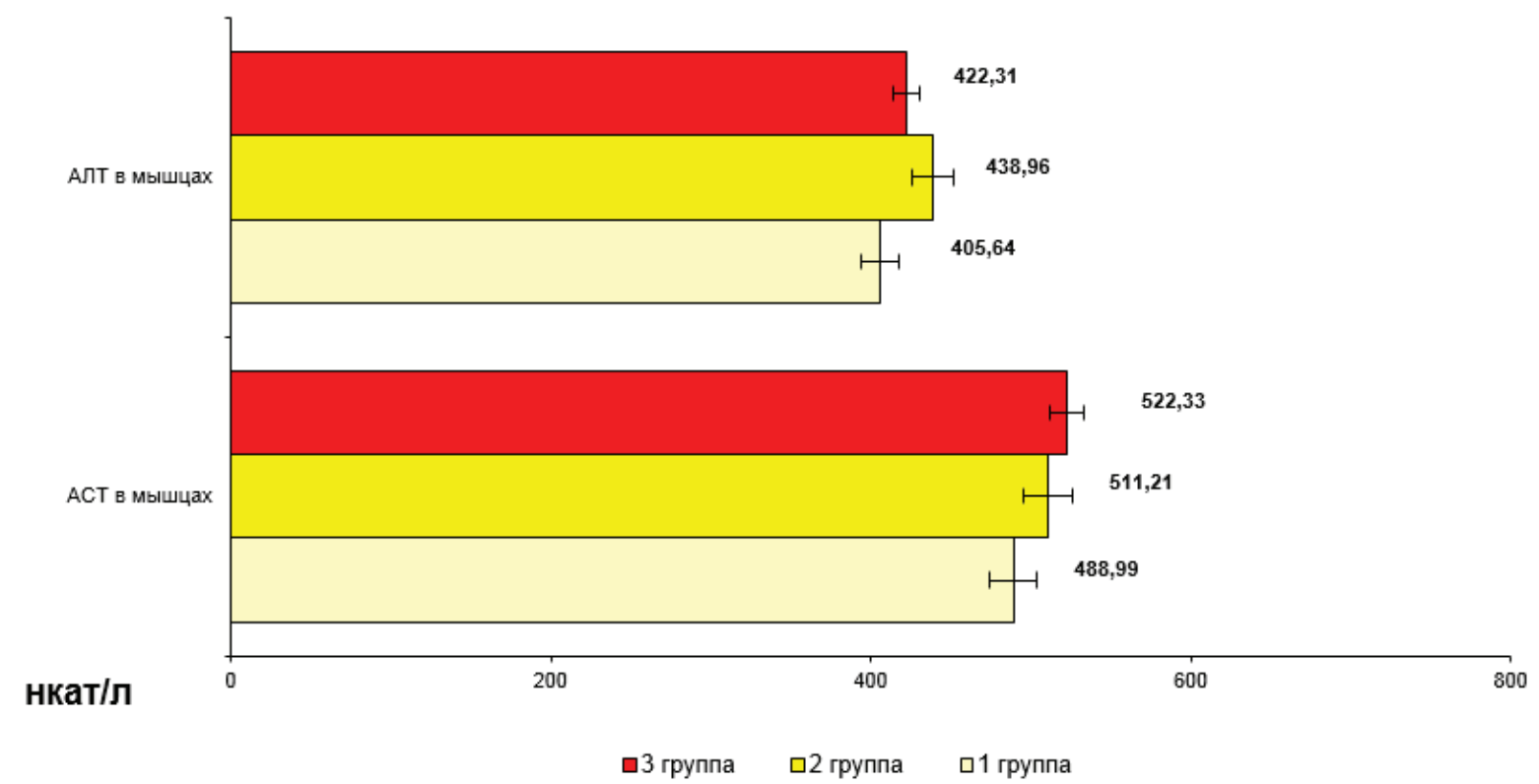

Рис. 2 - Активность аминотрансфераз в мышечной ткани поросят 210 -дневного возраста при использовании ЦЦК 


\section{Библиографический список}

1. Phenchenco, N. The influence of metal-iong of natural zeoiths of tuzbec logation on physiological organism functions /N. Phenchenco, M. Malikova, J. Salmanova //Trace elements in medicine. - 2002. Vol. 3, N. 2. - P. 33.

2. Виниченко, Г.В. Влияние природных минералов на ферменты переаминирования крови свиней в раннем постнатальном онтогенезе /Г.В. Виниченко, В.С. Григорьев //Известия ОГАУ. - 2010.№ 4. - С. 258-261.

3. Уровень некоторых минеральных элементов в крови коров на фоне применения цеолитсодержащей добавки /С.В. Фролова, Н.А. Любин, В.В. Ахметова, Л.И. Хайсанова // Проблемы сельскохозяйственного производства на современном этапе и пути их решения. Материалы 4-й международной научно-производственной конференции. - Белгород, 2000. - С. 154.

4. Разработка и внедрение нетрадиционных БАД, на основе натуральных компонентов в животноводство /Н.А. Любин, С.В. Дежаткина, В.В. Ахметова, С.Б. Васина, Т.М. Шленкина, Е.В. Свешникова, М.Е. Дежаткин: монография. -Ульяновск: УлГАУ, 2017. - 336 с.

5. Дежаткина, С.В. Динамика живой массы индеек при скармливании комплексной нанодобавки /С.В. Дежаткина, И.А. Никитина, М.Е. Дежаткин // Аграрная наука и образование на современном этапе развития: опыт, проблемы и пути их решения. IX Международная научно-практическая конференция. - Ульяновск, 2018. - С. 40-45.

6. Никитина, И.А. Использование сорбентов для получения экологически чистого мяса / И.А. Никитина //Наука и инновации в АПК XXI века. Всероссийская научно-практическая конференция молодых ученых, посвященная 145-летию Академии. - Казань, 2018. - С. 39-41.
7. Фисинин, В. Природные минералы в кормлении животных и птицы /В. Фисинин // Животноводство России. - 2008. - № 8. - С. 66-68.

8. Рациональное использование соевой окары в рационах молодняка свиней /С.В. Дежаткина, Н.А. Любин, А.В. Дозоров, М.Е. Дежаткин // Международный сельскохозяйственный журнал. - 2017. - № 5. - С. 40-44.

9. Любин, Н.А. Физиологические параметры обмена веществ у животных на фоне БУМВД соевой окары /Н.А. Любин, С.В. Дежаткина, М.Е. Дежаткин //Нива Поволжья. - 2017. - № 3 (44). - С. 59-63.

10. Свешникова, Е.В. Морфологический состав крови и продуктивный эффект препарата энтеродетоксимин В /Е.В.Свешникова, Н.А. Любин // Аграрная наука и образование на современном этапе развития: опыт, проблемы и пути их решения. Материалы конференции. - Ульяновск, 2016. - C. $160-165$.

11. Шленкина, Т.М. Минерализация костной ткани свиней в постнатальный период развития / Т.М. Шленкина // Научные открытия 2017. Материалы XXII Международной научно-практической конференции. -2017. -С. 150-151.

12. Kerr, B.J. Effect of feeding reduced protein amino acid-supplemented diets on nitrogen and energy balance in grower pigs /B.J. Kerr, R.A. Easter //J. Anim. Sci. - 1995. - V. 73. - P. 3000-3008.

13. The use of soy okara in feeding of pigs / S.V. Dezhatkina, N.A. Lubin, A.V. Dosorov, M.E. Dezhatkin // Research Journal of Pharmaceutical, Biological and Chemical Scinces. - 2016. - Tom 7, № 5. - C. 25732577.

14. Branched-chain amino acids for growing cattle limit-fed soybean hull-based diets /C.A. Loest, E.C. Titgemeyer, B.D. Lambert [et al.] //J. Anim. Sci. 2001. - V. 81. - P. 304-317.

\title{
PARAMETRES OF TISSUE METABOLISM OF ANIMALS IN CASE OF APPLICATION OF CITRATE ZEOLITE ADDITIVE
}

\author{
Akhmetova V.V., Mukhitov A.Z., Pulcherovskaya L.P. \\ FSBEI HE Ulyanovsk SAU \\ 432017, Ulyanovsk, Novyi Venets Boulevard, 1; tel .: 8 (8422) 55-23-75; \\ e-mail: verenka1111@mail.ru
}

Key words: metabolism, liver, muscle, animal, feed additive, zeolite.

The purpose of this work was to study the parameters of tissue metabolism of young pigs in case of application of zeolite in combination with organic acids. The experiment was conducted in the pig breeding farm of Ulyanovsk district in Ulyanovsk region. Analogues were selected for the experiment in accordance with breed, body weight, physiological state, age and productivity among young pigs aged up to 210 days. The scheme of feed supplements was that the first group of animals received only the main ration, this group was the control. The second group of piglets was fed with natural zeolite taken from deposits of Ulyanovsk region "Mainit" at a dose of $2 \%$ of the dry matter together with the main ration. The third group of young pigs was added to their basic ration citrate-zeolite complex once a day, which included $2 \%$ of zeolite from the dry matter of the ration and $40 \mathrm{mg} / \mathrm{kg}$ of citric acid. It is proved that the introduction of zeolite additives into the diet of piglets (separately and in combination with organic acids) affects the metabolism processes in the body tissues of productive animals. Activation of enzyme systems, synthesis of tissue protein in the liver and muscle tissue of young pigs occurs under the influence of catalytic and ion-exchange properties of the additives of the zeolite and citrate-zeolite complex, it contributes to an increase in their growth energy. A decrease of detoxification stress of pigs' liver when introducing zeolite additives and a complex based on zeolite and organic acids has been established.

Bibliography

1. Phenchenco, $N$. The influence of metal-iong of natural zeoiths of tuzbec logation on physiological organism functions /N. Phenchenco, M. Malikova, J. Salmanova //Trace elements in medicine. - 2002. - Vol. 3, N. 2. - P. 33.

2. Vinichenko, G.V. Influence of natural minerals on pigs blood transamination enzymes in early postnatal ontogenesis / G.V. Vinichenko, V.S. Grigoriev // Izvestiya OSAU. - 2010.- № 4. - P. 258-261. 
3. The level of some mineral elements in cows' blood in case of application of a zeolite-containing additive / S.V. Frolova, N.A. Lyubin, V.V. Akhmetova, L.I. Khaysanova // Problems of agricultural production at the present stage and ways to solve them. Proceedings of the 4th International Scientific and Production Conference. - Belgorod, 2000. - P. 154

4. Development and implementation of non-traditional dietary supplements, based on natural ingredients in animal breeding / N.A. Lyubin, S.V. Dezhatkina, V.V. Akhmetova, S.B. Vasina, T.M. Shlenkina, E.V. Sveshnikov, M.E. Dezhatkin: monograph. - Ulyanovsk: UISAU, 2017. - 336 p.

5. Dezhatkina, S.V. Live weight dynamics of turkeys when giving them a complex nano-additive / S.V. Dezhatkina, I.A. Nikitin, M.E. Dezhatkin // Agrarian science and education at the present stage of development: experience, problems and solutions. IX International Scientific and Practical Conference. Ulyanovsk, 2018. - P. 40-45.

6. Nikitina, I.A. The use of sorbents for production of ecologically pure meat / I.A. Nikitin // Science and Innovations in the AIC of the XXI Century. AllRussian scientific-practical conference of young scientists dedicated to the 145th anniversary of the Academy. - Kazan, $2018 .-$ P. 39-41.

7. Fisinin, V. Natural minerals in animal and poultry feeding / V. Fisinin // Animal Husbandry of Russia. - 2008. - № 8. - P. 66-68.

8. Appropriate use of soybean okara in diets of young pigs /S.V. Dezhatkina, N.A. Lyubin, A.V. Dozorov, M.E. Dezhatkin //International Agricultural Journal. - 2017. - № 5. - P. 40-44.

9. Lyubin, N.A. Physiological parameters of animal metabolism in case of application of protein, carbohydrate and mineral vitamin supplement of soybean okara / N.A. Lyubin, S.V. Dezhatkina, M.E. Dezhatkin // Niva of the Volga region. - 2017. - № 3 (44). - P. 59-63.

10. Sveshnikova, E.V. Blood morphological composition and the productive effect of Enterodetoksimin V medication / E.V. Sveshnikova, N.A. Lyubin // Agrarian science and education at the present stage of development: experience, problems and solutions. Conference proceedings. - Ulyanovsk, 2016. - P. 160-165.

11. Shlenkina, T.M. Bone tissue mineralization in the postnatal development period of pigs / T.M. Shlenkina // Scientific Discoveries in 2017. Materials of the XXII International Scientific and Practical Conference. -2017. -P. 150-151.

12. Kerr, B.J. Effect of feeding reduced protein amino acid-supplemented diets on nitrogen and energy balance in grower pigs /B.J. Kerr, R.A. Easter //J. Anim. Sci. - 1995. - V. 73. - P. 3000-3008.

13. The use of soy okara in feeding of pigs /S.V. Dezhatkina, N.A. Lubin, A.V. Dosorov, M.E. Dezhatkin //Research Journal of Pharmaceutical, Biological and Chemical Scinces. - 2016. - Tom 7, № 5. - C. 2573-2577.

14. Branched-chain amino acids for growing cattle limit-fed soybean hull-based diets / C.A. Loest, E.C. Titgemeyer, B.D. Lambert [et al.] // J. Anim. Sci. 2001. - V. 81. - P. 304-317. 